OPEN ACCESS

ISSN 2548-2246 (online) ISSN 2442-9139 (print)

Edited by:

lid Putri Zulaida

Reviewed by:

Paramitha Amelia K

*Correspondence:

Metha Fahriani

methafahriani42@gmail.com

Received: 06 Pebruari 2020

Accepted: 15 Pebruari 2020

Published: 05 Oktober 2020

Citation:

Fahriani M, Fusvita Sari S and Ramadhaniati Y (2020) Hubungan Usia dan Paritas Dengan Kejadian

Preeklampsia Pada Ibu Hamil di

Rumah Sakit Dr. M Yunus Bengkulu Tahun 2018.

Midwiferia Jurnal Kebidanan. 6:2. doi: 10.21070/midwiferia.v\%vi\%i.60
Hubungan Usia dan Paritas Dengan Kejadian Preeklampsia Pada Ibu Hamil di Rumah Sakit Dr. M Yunus Bengkulu Tahun 2018

\section{Relationship Of Age And Parity With Preeclampsia Incidence In Pregnant Women At dr. M. Yunus Hospital In Bengkulu}

\author{
Metha Fahriani*, Sefti Fusvita Sari, Yuni Ramadhaniati \\ Sekolah Tinggi Ilmu Kesehatan Tri Mandiri Sakti Bengkulu, Prodi DIV Kebidanan, Bengkulu, Indonesia
}

Preeklampsia merupakan kelainan yang ditemukan pada waktu kehamilan yang ditandai dengan berbagai gejala klinis seperti hipertensi, proteinuria, dan edema yang terjadi pada kehamilan. Pada tahun 2016 AKI di Bengkulu mencapai 224 per 100.000 kelahiran hidup. Salah satu penyebab AKI di Bengkulu yaitu Preeklampsia sebanyak (6,6\%). Tujuan dari penelitian ini adalah diketahui hubungan usia dan paritas dengan kejadian preeklampsia pada ibu hamil di RSUD dr. M. Yunus Bengkulu tahun 2018. Metode penelitian ini survey analitik dengan rancangan studi case control. Populasi dalam penelitian ini adalah seluruh ibu hamil di RSUD dr. M. Yunus Bengkulu tahun 2018. Pengambilan sampel penelitian ini dilakukan 1:1 seluruh variabel kasus (penderita preeklampsia) sebanyak 68 responden, diambil secara Total Sampling, sedangkan variabel kontrol (tidak preeklampsia) diambil secara Systematik Random Sampling yaitu tercatat di register rumah sakit. Hasil penelitian ini adalah tidak ada hubungan antara usia dan kejadian preeklamsia pada wanita hamil di RSUD dr. M. Yunus pada tahun 2018. Dengan nilai $\mathrm{p}=0,424>\alpha=0,05$ dan nilai Odds Ratio atau Risk Estimate $=1,496$, dan ada hubungan yang signifikan antara paritas dan kejadian preeklamsia pada wanita hamil di RSUD dr. M. Yunus Bengkulu pada tahun 2018. Dengan nilai $p=0,011<\alpha=0,05$ dengan kategori sedang. Diharapkan hasil penelitian ini dapat menjadi pengembangan program dan untuk perbaikan pelayanan dalam menurunkan prevalensi kejadian preeklampsia.

\footnotetext{
Keywords: Kejadian, Kehamilan, Usia, Paritas, Preeklampsia.
}

Preeclampsia is a disorder that is found during pregnancy which is characterized by various clinical symptoms such as hypertension, proteinuria, and edema that occur in pregnancy. In 2016 the Maternal Mortality Rate in Bengkulu reached 224 per 100,000 live births. One of the causes of maternal mortality in Bengkulu is preeclampsia (6.6\%). The purpose of this study is to know the relationship of age and parity with the incidence of preeclampsia in pregnant women at dr. M. Yunus Hospital in Bengkulu year 2018. This research method is analytic survey with case control study design. The population in this 
study were all pregnant women in dr. M. Yunus Hospital in Bengkulu year 2018. The sampling of this study was carried out 1:1 of all case variables (preeclampsia sufferers) of 68 respondent, taken by Total sampling, while the control variable (not preeclampsia) was taken Systematic Random Sampling, technique that is sampling using multiples recorded in the hospital register. The results of this study there is no relationship between age and the incidesnce of preeclampsia in pregnant women at RSUD dr. M. Yunus in 2018. With the value of $\mathrm{p}=0.424>\alpha=0.05$ and the value of Odds Ratio or Risk Estimate $=1.496$ and there is a significant relationship between parity and the incidence of preeclampsia in pregnant women at RSUD dr. M. Yunus Bengkulu in 2018. With the value of $p=$ $0.011<\alpha=0.05$ with the medium category.It is expected that the results of this study can be a program development and service improvement in reducing the prevalence of preeclampsia.

Keywords: Occurrence, Pregnancy, Age, Parity, Preeclampsia.

\section{PENDAHULUAN}

Kematian ibu merujuk pada kematian karena komplikasi dari kehamilan atau persalinan. Menurut WHO pada tahun 2015 jumlah AKI sebanyak 216 kematian per 100.000 kelahiran hidup. Lebih dari 800 ibu meninggal setiap harinya akibat komplikasi kehamilan dan persalinan yang disebabkan oleh perdarahan (27\%), hipertensi atau preeklampsia (14\%), Infeksi (11\%), Abortus (8\%), Emboli (3\%), kematian tidak langsung (28\%) dan kematian langsung (10\%). UNICEF (2020)

AKI di Indonesia saat ini masih tinggi. Berdasarkan hasil Direktorat Kesehatan Ibu penyebab langsung kematian ibu adalah perdarahan mencapai (31\%), preeklampsia sebesar (25\%), gangguan sistem perdarahan (13,0\%), infeksi sebesar (6\%), gangguan metabolik (3\%), dan lain - lain sebanyak 35\%. Perempuan (2018)

Kehamilan merupakan proses fisiologis tetapi banyak sekali penyulit dapat mengakibatkan tingginya kematian maternal salah satunya adalah preeklampsia. Sekitar $13 \%$ wanita berusia 15 - 20 tahun lebih memiliki resiko tinggi baik untuk ibu maupun janinnya, wanita berusia 35 tahun memperlihatkan peningkatan bermakna dalam insiden hipertensi atau preeklampsia. Angka kematian ibu lebih tinggi pada wanita yang memiliki usia ekstrim yaitu $<20$ dan $>35$. Dan $85 \%$ preeklampsia terjadi pada primigravida. Paritas 2 - 3 merupakan paritas paling aman ditinjau dari kejadian preeclampsia dan resiko meningkat lagi pada grandemultipara. Erlita and Iit (2017)

Wanita hamil dengan usia diatas 35 tahun akan mengalami perubahan fisiologis tubuh seperti vaso spasme, aktivasi berlebihan sistem koagulasi dan gangguan hormonal yang akan berdampak berkurangnya produksi prostasiklin sebagai vasodilator kuat, selain itu akan terjadi agregasi sel trombosit pada sel endotel yang rusak dan menyebabkan produksi berlebihan vasokonstriktor tromboksan. Kadar tromboksan jauh lebih tinggi dibandingkan kadar prostasiklin sehingga terjadi vasokonstriksi terus menerus dan peningkatan tekanan darah. Martadiansyah et al. (2019)

Ibu yang berumur kurang dari 20 tahun berisiko mengalami preeklampsia karena organ reproduksi belum terbentuk secara sempurna. Usia terlalu muda dalam menjalani proses kehamilan akan berpengaruh terhadap kematangan organ reproduksi dan komplikasi - komplikasi yang akan terjadi salah satunya yaitu preeklampsia. Retnawati and Suryanti (2017)

Ibu paritas primipara akan terjadi pembentukan "Human Leucocyte Antigen Protein G (HLA)" yang berperan penting dalam modulasi respon imunitas, sehingga ibu menolak hasil konsepsi (plasenta) atau terjadi intoleransi ibu terhadap plasenta sehingga terjadi preeklampsia. Sedangkan ibu dengan paritas grandemultipara sudah mengalami penurunan fungsi sistem reproduksi sehingga menyebabkan preeklampsi. Veftisia and Khayati (2018)

Upaya yang dapat dilakukan untuk menurunkan angka kesakitan dan kematian ibu yaitu melakukan deteksi dini tanda dan bahaya dalam kehamilan. Melalui tanda - tanda klinis pada saat perawatan antenatal dengan pemantauan kenaikan tekanan darah, proteinuria, kenaikan 
berat badan selama kehamilan dan status gizi serta menhindari faktor - faktor yang beresiko untuk terjadinya preeclampsia kehamilan. Arti et al. (2017)

Di Provinsi Bengkulu pada tahun 2016 AKI mencapai 224 per 100.000 kelahiran hidup. Penyebab AKI di Bengkulu yaitu karena perdarahan (53,33\%), hipertensi/preeklampsia (6,6\%), dan lain - lain (40\%). Pada tahun 2017 jumlah kematian ibu yaitu 28 orang, yang terdiri dari kematian ibu hamil sebanyak 6 orang, kematian ibu bersalin sebanyak 10 orang dan kematian ibu nifas sebanyak 12 orang. Angka kematian ibu di Provinsi Bengkulu pada tahun 2017 sudah mencapai target yang ditetapkan yaitu sebesar 79 per $100.000 \mathrm{KH}$. Bengkulu and Bengkulu (????)

Berdasarkan hasil data 3 tahun terakhir Dinas Kesehatan Kota Bengkulu kejadiaan preeklampsia pada ibu hamil di Kota Bengkulu yaitu pada tahun 2015 sebanyak 64 ibu hamil, pada tahun 2016 sebanyak 31 ibu hamil dan pada tahun 2017 sebanyak 27 ibu hamil. 2019 (????)

Data perbandingan kejadian preeklampsia di 3 Rumah Sakit Provinsi Bengkulu. Pada tahun 2018 urutan tertinggi berada di RSUD M. Yunus Bengkulu sebanyak 68 kasus, urutan kedua di Rumah Sakit Bhayangkara TK III Bengkulu sebanyak 33 kasus dan urutan ke tiga di RSUD Harapan dan Doa sebanyak 20 kasus. Jadi total dari 3 rumah sakit sebanyak 103 kasus preeklampsia.

Pengambilan penelitian tentang preeklampsia pada ibu hamil di RSUD dr. M. Yunus Bengkulu tahun 2018 disebabkan karena kejadian preeklampsia merupakan salah satu masalah patologi terbanyak yang terjadi di RSUD dr. M. Yunus Bengkulu tahun 2018.

\section{METODE}

Penelitian telah dilaksanakan pada tanggal 05 Juli - 11 juli di RSUD Dr. M. Yunus Bengkulu tahun 2019. Desain penelitian ini menggunakan metode survey analitik dengan rancangan studi case control.

Populasi dalam penelitian ini adalah seluruh ibu hamil di RSUD Dr. M. Yunus Bengkulu pada tahun 2018 sebanyak 603 ibu hamil yang terdiri dari 68 ibu hamil dengan preeklampsia.

Pengambilan sampel penelitian ini dilakukan 1:1 seluruh variabel kasus (penderita preeklampsia) sebanyak 68 responden, diambil secara Total Sampling, sedangkan variabel kontrol (tidak preeklampsia) diambil secara Systematik Random Sampling total sampel yaitu sebanyak 136 sampel.. Teknik Pengumpulan Data menggunakan data sekunder. Teknik Analisa Data menggunakan Analisis Univariat dan Analasis Bivariat, Digunakan untuk mengetahui hubungan antara dua variabel (independen dan dependen) dengan menggunakan uji statisktik Chi-Square ( ) dengan Contigency Coefficient dan diolah menggunakan program komputerisasi dengan tingkat kepercayaan $95 \%$ atau a $=0,05$. Untuk melihat faktor resiko dari angka kejadian penyakit pada kelompok yang berisiko dibanding angka kejadian pada kelompok yang tidak berisiko, digunakan Odd ratio (OR).

\section{HASIL PENELITIAN}

\section{Analisis Univariat}

Analisis univariat dilakukan untuk melihat gambaran distribusi frekuensi masing - masing variabel yaitu independen (Usia dan Paritas) dan variable dependen (Preeklampsia). Setelah penelitian dilaksanakan maka diperoleh data sebagai berikut :

\begin{tabular}{llll}
\multicolumn{2}{c}{ TABLE $\mathbf{1}$ | } & Gambaran Preeklampsia di RSUD dr. M. & Yunus Bengkulu bulan Januari - Desember Tahun 2018 \\
\hline No & Preeklampsia & Frekuensi & Persentase (\%) \\
1 & Ya & 68 & 50 \\
2 & Tidak & 68 & 50 \\
& Jumlah & 136 & 100 \\
\hline
\end{tabular}

BerdasarkanTabel 1 diketahui bahwa dari 136 ibu hamil di RSUD dr. M. Yunus Bengkulu 
tahun 2018, terdapat $68 \mathrm{ibu}$ hamil mengalami preeklampsia sebagai sampel kasus dan $68 \mathrm{ibu}$ hamil yang tidak mengalami preeklampsia sebagai sampel kontrol.

TABLE 2 | Gambaran Usia di RSUD dr. M. Yunus Bengkulu Tahun 2018

\begin{tabular}{llll}
\hline No & Usia & Frekuensi & Persentase (\%) \\
1 & $<20$ atau $>$ 35 tahun & 33 & 24.3 \\
2 & $20-35$ tahun & 103 & 75.7 \\
& Jumlah & 136 & 100 \\
\hline
\end{tabular}

Berdasarkan Tabel 2 diketahui bahwa 136 ibu hamil di RSUD dr. M. Yunus Bengkulu Tahun 2018 terdapat 33 ibu hamil dengan usia $<20$ atau $>35$ tahun sedangkan 103 ibu hamil dengan usia 20 - 35 tahun.

TABLE 3 | Gambaran Usia di RSUD dr. M. Yunus Bengkulu Tahun 2018

\begin{tabular}{llll}
\hline No & Paritas & Frekuensi & Persentase (\%) \\
1 & Grande multigravida & 44 & 32.4 \\
2 & Primigravida & 33 & 24.3 \\
3 & Multigravida & 59 & 43,4 \\
& Jumlah & 136 & 100 \\
\hline
\end{tabular}

Berdasarkan Tabel 3 diketahui dari $136 \mathrm{ibu}$ hamil di RSUD dr. M. Yunus Bengkulu bulan Januari - Desember Tahun 2018 terdapat 44 ibu hamil dengan paritas Grande multigravida, sedangkan 33 ibu hamil dengan paritas Primigravida dan 59 ibu hamil dengan paritas Multigravida.

\section{Analisis Bivariat}

Analisis bivariat ini dilakukan untuk mengetahui hubungan antara Variabel Independen (Usia dan Paritas) dan Variabel Dependen (Preeklampsia) dengan menggunakan uji statistic Chi-square. Adapun hasil analisis dapat dilihat pada tabel berikut :

TABLE 4 | Hasil analisis hubungan usia dengan kejadian preeklampsia di RSUD dr. M. Yunus Bengkulu Tahun 2018

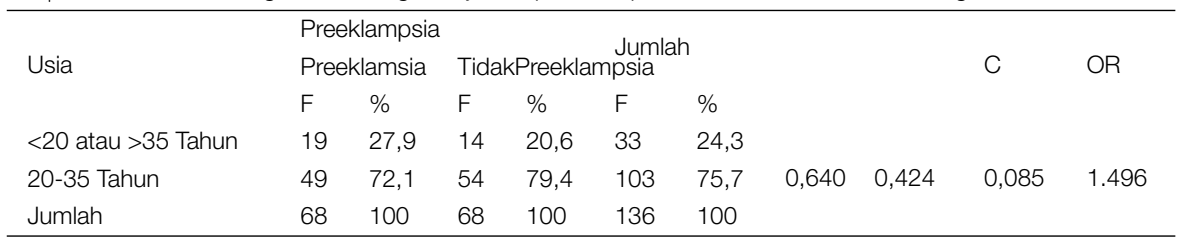

Dari Tabel 4 terlihat tabulasi silang antara usia dengan kejadian preeklampsia. Dari 33 ibu hamil usia<20 atau $>35$ tahun terdapat 19 ibu hamil yang mengalami preeklampsia dan $14 \mathrm{ibu}$ hamil yang tidak mengalami preeklampsia. Dari 103 ibu hamil usia 20-35 tahun terdapat 49 ibu hamil yang mengalami preeklampsia dan $54 \mathrm{ibu}$ hamil yang tidak mengalami preeklampsia.

Dari hasil uji Chi-square didapat nilai Continuity Correction ( ) =0,640 dengan nilai Asymp.sig $(p)=0,424>\alpha=0,05$ berarti tidak signifikan, maka diterima dan ditolak, artinya tidak ada hubungan yang signifikan antara usia dengan kejadian preeklampsia di RSUD dr. M. Yunus Bengkulu Tahun 2018 dengan hasil analisis didapatkan nilai Odds Ratio atau Risk Estimate sebesar 1,496 yang berarti ibu hamil yang berusia $<20$ atau $>35$ tahun beresiko 1,496 kali beresiko untuk terkena preeklampsia dibandingkan dengan ibu hamil yang berusia 20 - 35 tahun.

Dari Tabel 5 terlihat tabulasi silang antara paritas dengan kejadian preeklampsia. Dari 44 ibu hamil Grande multigravida terdapat 30 ibu hamil yang mengalami preeklampsia dan 14 ibu hamil yang tidak mengalami preeklampsia. Dari 33 ibu hamil primigravida terdapat $12 \mathrm{ibu}$ hamil yang mengalami preeklampsia dan $21 \mathrm{ibu}$ hamil yag tidak mengalami preeklampsia. Dari 59 ibu hamil multigravida terdapat 26 ibu hamil yang mengalami preeklampsia dan 33 ibu hamil yag tidak mengalami preeklampsia.

Dari hasil uji pearson Chi-square didapat sebesar $(\alpha)=9,103$ dengan nilai Asymp.sig $(p)$ $=0,011<\alpha=0,05$ berarti signifikan, maka ditolak dan diterima, artinya ada hubungan yang signifikan antara paritas dengan kejadian preeklampsia di RSUD dr. M. Yunus Bengkulu Tahun 2018. 
TABLE 5 | Hasil analisis hubungan paritas dengan kejadian preeklampsia di RSUD dr. M. Yunus Bengkulu Tahun 2018

\begin{tabular}{|c|c|c|c|c|c|c|c|c|c|}
\hline \multirow{3}{*}{ Paritas } & \multicolumn{4}{|c|}{ Preeklampsia } & \multirow{2}{*}{\multicolumn{2}{|c|}{ Jumlah }} & & & \multirow{3}{*}{$\mathrm{C}$} \\
\hline & \multicolumn{2}{|c|}{ Preeklampsia } & \multicolumn{2}{|c|}{ TidakPreeklampsia } & & & & & \\
\hline & $\mathrm{F}$ & $\%$ & $\mathrm{~F}$ & $\%$ & $\mathrm{~F}$ & $\%$ & & & \\
\hline Grande & 30 & 44,1 & 14 & 20,6 & 44 & 32,4 & & & \\
\hline Multigra & & & & & & & 9,103 & 0,011 & 0,250 \\
\hline Primigra & a12 & 17,6 & 21 & 30,9 & 33 & 24,3 & & & \\
\hline Multigra & a 26 & 38,2 & 33 & 48,5 & 59 & 43,4 & & & \\
\hline Jumlah & 68 & 100 & 68 & 100 & 136 & 100 & & & \\
\hline
\end{tabular}

Hasil uji contingency coefficient didapat nilai $\mathrm{C}=0,250$ dengan nilaip (Asymp.sig) $=0,011<$ $\alpha=0,05$ berarti signifikan. Berdasarkan nilai $p$ (Asymp.sig) $=0,011<\alpha=0,05$ maka adanya hubungan paritas dengan kejadian preeklampsia. Karena nilai $\mathrm{C}=0,250$ tidak jauh dari nilai $=0,577$ maka hubungan tersebut dikatakan kategori sedang.

\section{PEMBAHASAN}

Berdasarkan hasil penelitian diketahui bahwa dari 33 ibu hamil usia $<20$ atau $>35$ tahun terdapat $19 \mathrm{ibu}$ hamil yang mengalami preeklampsia dan 14 ibu hamil yang tidak mengalami preeklampsia. Dari 103 ibu hamil usia 20-35 tahun terdapat 49 ibu hamil yang mengalami preeklampsia dan 54 ibu hamil yang tidak mengalami preeklampsia.

Pada usia $<20$ atau $>35$ tahun terdapat 19 ibu hamil yang mengalami preeklampsia. Di usia muda $<20$ tahun belum siapnya organ reproduksi untuk persiapan kehamilan dan persalinan sedangkan usia $>35$ tahun terjadinya penurunan pada fungsi organ tubuh serta terdapat nya paritas yang berisiko. Usia $<20$ atau $>35$ tahun terdapat 14 ibu hamil tidak preeklampsia berdasarkan penelitian terdapat diagnosa lain pada ibu seperti: KPSW, anemia, hipertensi kronik, dan abortus inkomplit.

Berdasarkan hasil penelitian pada usia produktif 20 - 35 tahun masih terdapat 49 ibu hamil yang mengalami preeklampsia disebabkan oleh ibu mengalami faktor risiko lainnya yang bisa menyebabkan preeklampsia seperti kehamilan ganda, adanya riwayat preeklampsia sebelumnya dan terdapat diagnosa lain pada ibu seperti : anemia, molahidatidosa, hyperemesis gravidarum, polihidramnion, oligohidramnion, HBSAG+, KPSW, abortusinkomplit, hipertensikronik, dan KPD. Penelitian ini sejalan dengan penelitian Retnawati and Suryanti (2017) yang menjelaskan bahwa ibu hamil yang berusia $<20$ tahun dan $>35$ tahun beresiko untuk terkena preeklampsia dibandingkan dengan ibu hamil yang berusia antara 20 - 35 tahun.

Berdasarkan hasil penelitian dan analisis diketahui bahwa antara paritas dengan kejadian preeklampsia dari ibu hamil Grande multigravida terdapat 30 ibu hamil yang mengalami preeklampsia sedangkan dari ibu hamil Primigravida terdapat 12 ibu hamil yang mengalami preeklampsia dan dari 59 ibu hamil Multigravida terdapat 26 ibu hamil yang mengalami preeclampsia.

Ibu hamil grande multigravida dengan kejadian preeklampsia disebabkan karena paritas yang berisiko dan usia berisiko, sejalan dengan penelitian Veftisia,dkk (2018) salah satu faktor resiko yang berkaitan dengan preeklampsia yaitu paritas tinggi (lebih dari tiga), mengalami penurunan fungsi sistem reproduksi selain itu biasanya ibu terlalu sibuk mengurus rumah tangga sehingga sering mengalami kelelahan dan kurang memperhatikan pemenuhan gizinya.

Primigravida dapat terjadinya preeklampsia sesuai dengan teori bahwa kehamilan pertama terjadi pembentukan "Human Leucocyte Antigen Protein G (HLA)" yang berperan penting dalam modulasi respon imunitas sehingga ibu menolak hasil konsepsi (plasenta) atau terjadi intoleransi ibu terhadap plasenta sehingga terjadi preeklampsia.

Berdasarkan hasil penelitian masih adanya paritas multigravida yang mengalami preeklampsia disebabkan oleh adanya riwayat preeklampsia sebelumnya, terdapat usia yang berisiko dan terdapat diagnosa lain pada ibu seperti: anemia, hyperemesis gravidarum, polihidramnion, KPSW, hipertensi kronik, abortus inkomplit, oligo hidramnion dan trombositopenia. Berdasarkan penelitian paritas multigravida tidak terjadi preeklampsia dikarenakan paritas multigravida merupakan paritas paling aman ditinjau dari kejadian preeklampsia.

Hasil penelitian ini sejalan dengan penelitian Rahmawati (2019) dengan judul penelitian Resiko Umur Dan Paritas Ibu Hamil Pada Kejadian Preeklampsia Eklampsia, didapatkan 
hasil hubungan yang bermakna antara paritas dengan kejadian preeklampsia. Oleh karena itu sebaiknya ibu hamil melakukan pendeteksian secara dini agar tidak terjadi komplikasi pada kondisi obstetrik yang dapat menyebabkan terjadinya preeklampsia serta mengikuti kelas ibu hamil, selanjutnya juga menurut penelitian Retnawati and Suryanti (2017) menyatakan ada hubungan antara paritas dengan preeklampsia terutama pada primipara. Karena pada primipara sering mengalami setres karena akan menghadapi persalinan. Setresakanmenimbulan emosi yang tidak terkontrol sehinggga dapat mengganggu kinerja organ jantung dalam memompa darah seluruh tubuh. Hal ini akan menyebabkan terjadinya peningkatan tekanan darah.

\section{KESIMPULAN}

1. Dari 136 ibu hamil terdapat 68 (50\%) ibu hamil mengalami preeklampsia dan 68 (50\%) ibu hamil tidak mengalami preeklampsia.

2. Dari 136 ibu hamil terdapat $33(24,3 \%)$ ibu hamil dengan usia $<20$ tahun atau $>35$ tahun dan 103 (75,7\%) ibu hamil dengan usia 20-35 tahun.

3. Dari 136 ibu hamil terdapat $44(32,4 \%)$ ibu hamil dengan paritas Grande multigravida, 33 $(24,3 \%)$ ibu hamil dengan paritas Primigravida dan $59(43,4 \%)$ ibu hamil dengan paritas Multigravida.

4. Tidak ada hubungan antara usia dengan kejadian preeklampsia pada ibuhamil di RSUD dr. M. YunusTahun 2018.

5. Ada hubungan yang signifikan antara paritas dengan kejadian preeklampsia pada ibu hamil di RSUD dr. M. Yunus Bengkulu Tahun 2018.

\section{REFERENCES}

2019, D. K. P. B. T. (????). Profil Kesehatan Provins Bengkulu Tahun 2018. Jl. Indra Giri No. 02 Padang Harapan BengkuluTelpon : 0736-22428, 343549Fax no:0736-22428, 343549Web: dinkes.bengkuluprov.go.id. https://www.kemkes.go.id/resources/download/profil/ PROFIL_KES_PROVINSI_2018/07_Bengkulu_2018. pdf.

Arti, F. Y., Wijayanti, W., and Ivantarina, D. (2017) Analisis Perilaku Kesehatan dan Faktor Resiko Kejadian Preeklampsia Pada Ibu Hamil di Poliklinik Obstetri Gynekologi RSUD Kabupaten Kediri. Journal of Issues in Midwifery 01, 1-17. doi: :http://dx.doi.org/10.21776/ub. JOIM.2017.001.03.1.

Bengkulu, P. K. and Bengkulu, D. K. K. (????) Profil Kesehatan Kota Bengkulu Tahun 2016. PROFILKESEHATANKOTABENGKULUTAHUN2016PEMERINTAHKOTABENGKULUDINAS KESEHATAN KOTA BENGKULUJL. BASUKI RAHMAT TELP. 0736-21072TAHUN 2017. https://www.kemkes. go.id/resources/download/profil/PROFIL_KAB_KOTA_ 2016/1771_Bengkulu_Kota_Bengkulu_2016.pdf.

Erlita, C. and Iit, K. (2017). Faktor - Faktor yang Berhubungan dengan Preeklamsia Berat pada Ibu Bersalin di Rumah Sakit TK II KartikaHusadaKabupatenKubu Raya Tahun. Jurnal Kebidanan 7, 63-63. e-ISSN 2620-4894.

Martadiansyah, A., Qalbi, A., and Santoso, B. (2019) Prevalensi Kejadian Preeklampsia dengan Komplikasi dan Faktor Risiko yang Mempengaruhi di RSUP Dr. Mohammad Hoesin Palembang. Sriwijaya Journal Of Medicine 2, 19-19.

Perempuan, Y. K. (2018). Akses Universal Pelayanan Kese- hatan Seksual Dan Reproduksi. http://ykp2015.com/wpcontent/uploads/Indonesia-SRHR-Services.pdf.

Retnawati, S. A. and Suryanti, S. (2017). Hubungan Antara Usia, Paritas dan Perilaku Asupan Zat Gizi dengan Kejadian Pre Eklampsia pada Ibu Hamil Di RSUD Provinsi Kepri Tahun. Jurnal Cakrawala Kesehatan Kumpulan Jurnal Kesehatan.

UNICEF (2020). Trends in estimates of maternal mortality ratio (MMR), maternal deaths and lifetime risk of maternal death, 2000-2017. Maternal mortality fell by almost half between. https://data.unicef.org/topic/maternal-health/ maternal-mortality/.

Veftisia, V. and Khayati, Y. N. (2018). Hubungan Paritas Dan Pendidikan IbuDenganKejadianPreeklampsia Di Wilayah Kabupaten Semarang. Jurnal SIKLIS 07, 337-337. doi: http://dx.doi.org/10.30591/siklus.v7i2.830.

Conflict of Interest Statement: The authors declare that the research was conducted in the absence of any commercial or financial relationships that could be construed as a potential conflict of interest.

Copyright (C) 2020 Fahriani, Fusvita Sari and Ramadhaniati. This is an open-access article distributed under the terms of the Creative Commons Attribution License (CC BY). The use, distribution or reproduction in other forums is permitted, provided the original author(s) and the copyright owner(s) are credited and that the original publication in this journal is cited, in accordance with accepted academic practice. No use, distribution or reproduction is permitted which does not comply with these terms. 